\title{
Microbial Ecosystem in Diabetes Mellitus: Consideration of the Gastrointestinal System
}

\author{
Awgichew Shewasinad \\ Yehualashet $\mathbb{D}$ \\ Berhan Begashaw Yikna (10) \\ Pharmacology and Toxicology Unit, \\ Department of Pharmacy, College of \\ Health Sciences, Debre Berhan \\ University, Debre Berhan, Ethiopia
}

\begin{abstract}
Intestinal microbiota is established to be a crucial element in the control of human health, and keeping the symbiotic relationship between the human body and intestinal microbes will have paramount importance. A number of investigations illustrated that many chronic diseases are associated with intestinal micro-ecological disorders implying intestinal floras as an important component among the environmental factors, and perturbations in their composition are correlated with metabolic disorders, including obesity and diabetes mellitus (DM). Increased evidence suggests that alterations in the gut microbial ecosystem have been involved in part in the pathogenesis of both type 1 and type 2 DM. Short chain fatty acids (SCFAs), derived from microbiota, have been studied for their potential action in modulating CNS, gut barrier axis, and the immune system as a promising mechanism for the observed protective effects on diabetes pathogenesis. Besides, the role of bile acid (BA) stimulated receptors to have a significant role in liver metabolism, and pathophysiology of liver-based metabolic diseases has also been investigated. In the current review, we will try to summarize the correlation between intestinal microbiota and diabetes considering the existing current evidence revealing the role of gut microbiota in onset and disease progression.
\end{abstract}

Keywords: gut microbiota, intestinal flora, microbial ecosystem, diabetes mellitus

\section{Introduction}

Diabetes mellitus (DM) is a chronic hyperglycemic condition as a result of pancreatic $\beta$ cell dysfunction or insulin resistance, known to cause macrovascular and microvascular complications. ${ }^{1,2}$ The cause of defect in carbohydrate, fat, and protein metabolism in DM is the compromised action of insulin on its targets. $^{3,4}$

Genetic predisposition and environmental factors are among the crucial elements in the pathogenesis of DM. Out of the environmental factors accounting for the disease; gut microbiota has been regarded as a potential contributory factor associated with the disease. Gastrointestinal microbiome is established to be a key element in controlling human health, and maintenance of the symbiotic relationship between the human body and gut microbes will have paramount importance. Numerous investigations have revealed that many chronic diseases are related to intestinal microecological disorders implying intestinal flora as an important component among the environmental factors, and its modifications could lead to some sort of metabolic problems like diabetes and obesity. 5,6
Correspondence: Awgichew Shewasinad Yehualashet

Pharmacology and Toxicology Unit, Department of Pharmacy, College of Health Sciences, Debre Berhan University, PO Box 445, Debre Berhan, Ethiopia

Tel +25 I 935450290

Email awgshewa@gmail.com 


\section{Gut Microbiota and Diabetes}

Homeostasis can be maintained as a result of a mutual interaction between the human host and gut microbes, therefore, any dysregulation to the normal composition of commensal communities, the so-called 'dysbiosis' could weaken the homeostasis and contribute in the emergence of many autoimmune disorders. With the help of highthroughput sequencing technologies, aggregate evidence has illustrated that there are visible variations in the profile of intestinal microbial between type 1 diabetic patient and the controls, implying a close interaction between gut microbiota and diabetes. Consequently, a number of studies have suggested that changes in gut microbiota composition have got a place in the pathogenesis of the disease. However, whether these microbial changes are causal, responsive, or both are becoming an active area of investigations requiring scrutiny in the scientific community. In this review, we will discuss the association between intestinal microbiota and diabetes considering the existing animal and human evidence revealing the influence of the gut microbial ecosystem in onset and disease progression. ${ }^{5-7}$

The microbiota is regarded as microbial ecosystems living together in a symbiotic interaction with their host, sheltered on skin, respiratory, and urogenital systems and the intestinal tract. Among the variety of microorganisms found in the gut, bacteria are relatively best studied. ${ }^{7,8}$ There are around a hundred trillion cells of microbes in the human gut, which is 10-times higher compared to the number of human cells. The majority of microbiota of the gut are categorized into the following phyla: Firmicutes, Bacteroidetes, Actinobacteria, and Proteobacteria. The intestinal microbiota so-called "hidden organ" is involved invarious physiological functions such as fighting against pathogens, energy production, intestinal epithelial integrity maintenance, and immune regulation. ${ }^{9}$

Functionally, the vital role of the gut is enhancing digestion of food, absorption of nutrients, helps in the removal of waste products, and protecting against invasion by pathogenic bacteria. The protective mechanism is by acting as an impermeable barrier on intestinal epithelial cells along with other cells. ${ }^{7,10}$ In addition, the gut gives protection against pathogen overgrowth, impeding their aggregation by inhibiting adherence, bacteriocin generation and nutrient competition. It participates in the metabolism of drugs, detoxification of exogenous toxins, synthesis of essential vitamins like B1, B2, B5, B6, B12,
$\mathrm{K}$, folic acid, and deconjugation of bile acids (BA). Moreover, the ability to ferment indigestible carbohydrates helps them to provide $5-10 \%$ of daily energy need. Besides, in the intact colon, it aids intestinal repair through enhancing cellular proliferation and differentiation which have a substantial role in the maintenance of gut integrity. ${ }^{7,10}$

Their role in maturation and continued education of the host's immunity has been pointed out with recent investigations. As a result of continued education, the immune system learned to identify the commensal from pathogenic bacteria where commensal bacteria can trigger an antiinflammatory response, while pathogenic bacteria provoke a pro-inflammatory condition. Hence, gut microbiota regulates migration and function of neutrophils and affects Tcell differentiation, favoring differentiation and expansion of regulatory T-cells (Tregs), which are crucial components in mediating immune tolerance. The ability of controlling the immune system is via generation of short-chain fatty acids (SCFAs), like butyrate, acetate, and propionate that are produced by bacterial fermentation of non-digestible carbohydrates. In $\mathrm{T}$ lymphocytes, SCFAs are employed in stimulating $G$ protein-coupled receptors (GPR41/GPR43) signaling cascades, inhibiting histone deacetylases, and eliciting metabolic changes via promoting the action of a mammalian target of rapamycin (mTOR) complex. Consequently, inflammatory cascades will be inhibited; triggering the expansion of mucosal Tregs, and generation of inflammatory cytokines like interleukin-10 (IL-10) and interferon- (IFN-) will be reduced. Provided that they have a key role in regulating health of the host, it is not amazing that dysbiosis could be implicated in the pathogenesis of various extra intestinal diseases including diabetes. ${ }^{7}$

\section{Changes of Intestinal Flora in Diabetic Populations}

Family history and environmental factors are key elements in the pathogenesis of diabetes. Among environmental factors, gut microbiota has been regarded as a potential contributory factor associated with type 1 diabetes. ${ }^{11,12}$ Studies showed that the microbiota has a linkage with weight gain and adiposity through many other related processes including energy harvest and formation of microbial metabolites, although their effect on inflammatory reactions and the gut-brain axis. One major metabolic function of gut microbiota is generating non-gaseous and 
absorbable SCFAs which are vital in modulating gut health and the immune system, promoting intestinal hormone production and lipogenesis. ${ }^{12}$

The anti-inflammatory effects of SCFAs is as a result of produced immunoglobulin $\mathrm{A}$ and immunosuppressive cytokines. Therefore, loss of early-life exposure because of continued use of antibiotics and a reduced fiber intake could end up with dysbiosis, which in turn allows the incidences of inflammatory problems, including diabetes. Several investigations have reported that the number of bacteria employed in generation of SCFA was significantly lowered in people with type 2 diabetes. SCFAs bind to GPCRs and result in enhancing the release of glucagonlike peptide-1 (GLP-1); which has an incretin effect and hinders glucagon release, prevents gluconeogenesis in the liver, ameliorates insulin sensitivity, and builds up central satiety, thereby resulting in bodyweight loss. Moreover, SCFAs can directly hamper the low-grade inflammatory response produced because of the migration of bacteria from the intestines into the mesenteric adipose tissue and the blood. ${ }^{13}$

Dietary fats promote absorption and removal from lipopolysaccharides (LPS) through intestinal/epithelial cells by inducing chylomicrons. LPS has an affinity for chylomicrons and is co-transported along with other dietary fats. Insulin insensitivity is associated with obesity and low-grade inflammation which is distinguished in part to alterations in gut microbiota. ${ }^{14}$ Different animal and human studies were conducted to evaluate whether changes are causal or merely a consequence of obesity or metabolic syndrome. To date, different animal and human investigations have been undertaken to evaluate the role of gut microbiota in the pathogenesis of both types of DM. In the table below, we have been tried to summarize the existing evidence showing the causal relationship between the disease and the gut microbiota.

\section{Evidence on the Role of Gut Microbiota in the Pathogenesis of Type I and Type 2 DM Current Evidence on the Role of Gut Microbiota in the Pathogenesis of Type I DM}

Until recently, the correlation between gut microbiota and pathogenesis of type $1 \mathrm{DM}$ has been investigated in animal models, the condition may better be elaborated with various cohort studies to recognize the alteration of intestinal microbiota abundance prior to occurrence of the disease.

Prospective studies can give information regarding progression of the disease in time, whereas etiological association could be obtained from interventional studies. Investigations in huge lines of children will be crucial to prove the involvement of microbiome disturbance prior to the development of type $1 \mathrm{DM}^{7,9}$ The aggregate evidence summarizing preclinical and clinical trials conducted to explore the correlation of microbiota and type 1DM have been presented in Table 1 .

\section{Current Evidence on the Role of Gut Microbiota in the Pathogenesis of Type 2 DM}

Alterations in the composition of intestinal microbiota is correlated with metabolic disease including type 2 DM. Different studies in animals showed various mechanisms contributing to the pathogenesis of the disease. ${ }^{12}$ Basically (as presented in Table 2), many of the investigations revealing the role of microbiota in glucose homeostasis are derived from studies in mice. But a change in the composition of microbiota has also been illustrated in a series of human cohort type 2 DM.

\section{Possible Mechanisms of Gut Microbiota in Diabetes Pathogenesis Mechanisms Involving SCFAs}

According to a hypothesis by Trowell, dietary changes are blamed for diabetes, and increased use of processed carbohydrates with a low level of dietary fiber (DF) has been regarded as one potential risk factor for diabetes. Major DFs include soluble fibers, like pectin, inulin, arabinoxylan, and hemicellulose, and insoluble fibers such as cellulose. The soluble fibers can be fermented by microbiota to produce SCFAs acetate, propionate, and butyrate. The generation of SCFAs in distal gut is via bacterial fermentation of macrofibrous material that might get out of digestion by upper gastrointestinal tract and reach the colon (Figure 1). Current findings showed the role of SCFAs in modulating CNS, gut barrier axis, and the immune system which are assumed to be promising mechanisms for the observed protective effects of DF on diabetes pathogenesis. Recent findings indicated that microbiota is modulated by SCFAs for their protective activity on type 1 diabetes pathogenesis. ${ }^{15,16}$ Moreover, evidence suggested 
Table I Evidence from Animal and Human Studies Revealing the Causal Relation between Gut Microbiota and Type I Diabetes

\begin{tabular}{|c|c|c|}
\hline Study/Method/Intervention & Outcome & Ref \\
\hline $\begin{array}{l}\text { Profiling of gut microbiota in Hun Chinese with type I } \\
\text { diabetes }\end{array}$ & $\begin{array}{l}\text { The findings indicated that Han Chinese type I diabetic patients showed clearly a } \\
\text { different microbiota as compared to the healthy controls, which are identified by an } \\
\text { increased ratio of Bacteroidetes/Firmicutes, negative association of Faecalibacterium } \\
\text { abundance with HbAlc, and a positive association of availability of Bacteroides with } \\
\text { autoantibodies. }\end{array}$ & {$[24]$} \\
\hline $\begin{array}{l}\text { Bacteriome at the onset of type I diabetes: A study from } \\
\text { four geographically distant African and Asian countries }\end{array}$ & $\begin{array}{l}\text { With the employment of four distinct case-control data sets from the faraway } \\
\text { communities of Africa and Asia, a significant positive correlation with type I diabetes } \\
\text { was shown for the genus Escherichia (class Gammaproteobacteria, phylum } \\
\text { Proteobacteria), while Eubacterium and Roseburia, two genera of class Clostridia, } \\
\text { phylum Firmicutes, were inversely correlated with the disease. It was also proved a } \\
\text { prior observed inverse association with Clostridium clusters IV or XIVa while no } \\
\text { correlations were observed for richness, evenness, or enterotypes. }\end{array}$ & {$[25]$} \\
\hline $\begin{array}{l}\text { Composition of fecal micriobita in children with } \beta \text {-cell auto } \\
\text { immunity and those without }\end{array}$ & $\begin{array}{l}\text { The result suggested that alterations in the intestinal bacterial diversity are observed } \\
\text { at pre-diabetes stage, and these changes precede the development of type I diabetes. } \\
\text { Further studies are recommended to see the functional changes in the intestinal } \\
\text { microbiota in course of time to evaluate the effect of gut microbiota in generating of } \\
\beta \text {-cell autoimmunity and type I diabetes. }\end{array}$ & {$[26]$} \\
\hline $\begin{array}{l}\text { A case control study on gut microbiota in children with type } \\
\text { I diabetes and healthy controls }\end{array}$ & $\begin{array}{l}\text { Type I diabetes and its correlation with intestinal microbiota have been studied. A } \\
\text { significant association was observed with the quantity of Bifidobacterium, } \\
\text { Lactobacillus and Clostridium and in the ratio of Firmicutes to Bacteroidetes within } \\
\text { the two groups, probably linked to the level of glucose in those with diabetes. } \\
\text { Besides, the amount of bacteria needed to stabilize the integrity of the gut was highly } \\
\text { reduced in diabetic children in comparison to the healthy ones. }\end{array}$ & {$[27]$} \\
\hline $\begin{array}{l}\text { A case control study on compositional and functional } \\
\text { difference in type I diabetic children and healthy controls }\end{array}$ & $\begin{array}{l}\text { There were differences in taxonomic and functionality of gut microbiota in type I } \\
\text { diabetic children than the healthy controls and from those with non-autoimmune } \\
\text { diabetes. }\end{array}$ & {$[28]$} \\
\hline $\begin{array}{l}\text { A pilot study on correlation of glycemic regulation and IL } \\
\text { with gut dysbiosis in autoimmune diabetes }\end{array}$ & $\begin{array}{l}\text { The imbalance in intestinal microbiota is associated with minimal glycemic regulation } \\
\text { and raised IL-6. The finding indicated a difference in gut microbiota composition in } \\
\text { type I diabetic cases compared to the healthy controls. The presence of } \mathrm{G}^{-\mathrm{ve}} \\
\text { bacteria in type I diabetic cases might participate in making the gut leaky, } \\
\text { translocation bacteria, and reducing glycemic regulation. }\end{array}$ & [29] \\
\hline $\begin{array}{l}\text { Different microbial and host proteins are available in gut } \\
\text { proteomic of diabetic cases and their controls }\end{array}$ & $\begin{array}{l}\text { The finding evidenced significant differences between gut proteome of children with } \\
\text { type I diabetes and controls. In those with diabetes, the availability of proteins of } \\
\text { cluster of clostardia XVa \& IV and bactriodes were found to be high. However, a high } \\
\text { amount of bifido-bactreial proteins were found in the proteome of the controls. In } \\
\text { diabetic cases and controls, secondary functions of proteins were seen and human } \\
\text { proteins can also characterize those diabetic cases. }\end{array}$ & {$[30]$} \\
\hline $\begin{array}{l}\text { Stating the autoimmune nature of gut microbiota for type I } \\
\text { diabetes mellitus }\end{array}$ & $\begin{array}{l}\text { The line of evidence obtained supports the notion that, as the age of healthy } \\
\text { newborn babies increases their microbiomes become healthier and more stable, } \\
\text { whereas children who are intended for autoimmunity may cause a microbiome to be } \\
\text { less diverse and stable. } \\
\text { In the autoimmune scenario, type I diabetics may be distinctly different from the } \\
\text { healthy ones and bacterial markers to be regarded as a diagnosis method for type I } \\
\text { diabetes were suggested. Therefore, bacteria that were negatively associated with } \\
\text { autoimmune state might be important in preventing the emergence of autoimmunity } \\
\text { in high-risk children. }\end{array}$ & [9] \\
\hline
\end{tabular}

(Continued) 
Table I (Continued).

\begin{tabular}{|c|c|c|}
\hline Study/Method/Intervention & Outcome & Ref \\
\hline $\begin{array}{l}\text { Microbiaa composition and Inflammatory condition in the } \\
\text { duodenum mucosa of type I diabetic patients }\end{array}$ & $\begin{array}{l}\text { An increase in the level of CCL13, CCL19, CCL22, CCR2, COX2, IL4R, CD68, } \\
\text { PTX3, TNFa, and VEGFA was seen in diabtetic patients in comparison to the control } \\
\text { groups and patients with celiac disease. Duodenal mucosal microbiome results in the } \\
\text { diabetic group were different from the other groups, with a rise in Firmicutes and } \\
\text { Firmicutes/Bacteroidetes ratio and a decrease in Proteobacteria and Bacteroidetes. } \\
\text { Because of the expression of genes specific for type I diabetes, inflammation was } \\
\text { correlated with the presence of specific bacteria in the duodenum. The study, } \\
\text { therefore, revealed that duodenal mucosa in type I diabetic patients presented } \\
\text { disease-related anomalies in the inflammatory condition and microbiota. }\end{array}$ & {$[31]$} \\
\hline $\begin{array}{l}\text { Analysis of metagenome of gut microbiota as a model in the } \\
\text { emergence of autoimmune diabetes }\end{array}$ & $\begin{array}{l}\text { The result suggested that increases in the synthesis of adhesion and flagella in } \\
\text { autoimmunity might be part of a triggering mechanism in type I diabetes and related } \\
\text { autoimmune response. Substantial dis-similarity in metabolic capacity showed that } \\
\text { autoimmune subjects have microbiomes which deviate functionally from the healthy } \\
\text { controls functionally abnormal microbiome. The finding indicated that a collection of } \\
\text { bacteria producing lactate- and butyrate in a healthy gut provokes adequate mucin } \\
\text { synthesis so as to maintain the integrity of the gut while, contrarily, non-butyrate- } \\
\text { producing lactate-utilizing bacteria avert sufficient mucin synthesis. }\end{array}$ & [32] \\
\hline $\begin{array}{l}\text { Distinct fecal and oral microbiota composition in human type } \\
\text { I diabetic cases, an observational study }\end{array}$ & $\begin{array}{l}\text { The study revealed that oral microbiota was remarkably different in type I diabetes } \\
\text { (eg, abundance of Streptococci) in comparison to healthy controls. Fecal investigations } \\
\text { indicated reduced butyrate producing species in type I diabetic patients and less } \\
\text { butyryl-CoA transferase genes. The plasma levels of acetate and propionate were } \\
\text { lowered in type I diabetes, with similar fecal SCFA and fecal strains Christensenella } \\
\text { and Subdoligranulum were associated with glycemic control, inflammatory } \\
\text { parameters, and SCFA. }\end{array}$ & [33] \\
\hline $\begin{array}{l}\text { Autoimmunity and intestinal colonization by Candida albicans } \\
\text { in type I diabetic patients while at diagnosis }\end{array}$ & $\begin{array}{l}\text { According to the evaluation, direct examination and culture of fresh stool samples } \\
\text { showed that } 50 \% \text { of the patients with type I diabetes and } 23.8 \% \text { of control subjects } \\
\text { presented with fungi ( } C \text {. albicans). It was therefore suggested that existence of } \\
\text { colonization of intestinal C. albicans during diagnosis of type I diabtes could show } \\
\text { hinderance to many normal intestinal microbiota. It was also suggested that there } \\
\text { might be a probability of type I diabetes in patients with a high C. albicans in their } \\
\text { intestine. }\end{array}$ & [34] \\
\hline $\begin{array}{l}\text { Dynamics of human infant gut microbiome in onset and } \\
\text { progression of type I diabetes }\end{array}$ & $\begin{array}{l}\text { A significant reduction in alpha-diversity was observed in type I diabetics in the time- } \\
\text { window between sero-conversion and type I diabetes diagnosis, accompanied by } \\
\text { spikes in inflammation-favoring organisms, gene functions, and serum and stool } \\
\text { metabolites. This study identified the course of development of human infant gut } \\
\text { microbiome along with specific alterations that precede onset of type I diabetes and } \\
\text { distinguish type I diabetes progressors from non-progressors. }\end{array}$ & [35] \\
\hline $\begin{array}{l}\text { Gut microbiata in children with type I diabetes and those } \\
\text { without }\end{array}$ & $\begin{array}{l}\text { Colonization of Bifidobacterium was reduced in diabetic cases compared to those } \\
\text { without, while colonization of Candida albicans and Enterobacteriaceae was raised, } \\
\text { but not Echerichia coli. This might disrupt the balance of intestinal flora and probably } \\
\text { could be a triggering factor in the etiologic mechanism of type I diabetes. }\end{array}$ & [36] \\
\hline $\begin{array}{l}\text { Deviating intestinal microbiota level in the emergence of type } \\
\text { I diabetes in young children }\end{array}$ & $\begin{array}{l}\text { In those }<2.9 \text { years, the aggregate availability of both class Bacilli (in particular } \\
\text { streptococci) and phylum Bacteroidetes was greater in diabetic children, while } \\
\text { clostridium clusters IV and XIVa were greater in healthy controls. Controls }>2.9 \\
\text { years were distinguished with a large amount of butyrate-producing species within } \\
\text { Clostridium clusters IV and XIVa than the younger age groups, and diabetic children } \\
>2.9 \text { years might be identified with the presence of more microbial diversity. The } \\
\text { findings concluded that non-diabetic children have a more balanced microbiota in } \\
\text { which butyrate-producing species seem to have a central role. }\end{array}$ & [37] \\
\hline
\end{tabular}


Table I (Continued).

\begin{tabular}{|c|c|c|}
\hline Study/Method/Intervention & Outcome & Ref \\
\hline $\begin{array}{l}\text { Faecal microbiota transplantation (FMT) in the onset of new } \\
\text { cases of human type I diabetes }\end{array}$ & $\begin{array}{l}\text { FMT ceases reduction of insulin release in type I diabetic individuals during a period } \\
\text { of I year starting from onset. Metabolic products obtained from micro biota and } \\
\text { bacterial strains could be responsible for the remaining role of ruminant } \beta \text { cells. }\end{array}$ & [38] \\
\hline $\begin{array}{l}\text { Oral butyrate and its role in immunity and islet auto- } \\
\text { immunity. A randomized controlled trial }\end{array}$ & $\begin{array}{l}\text { The study reported that oral butyrate administration in long-lasting type I diabetes } \\
\text { showed no change in peripheral blood innate and adaptive immunity. }\end{array}$ & [39] \\
\hline Intestinal microbiota in early-onset type I diabetes in humans & $\begin{array}{l}\text { The super-pathway of fermentation was higher in controls in the TID cohort helps } \\
\text { the biosynthesis of SCFAs showed increment in healthy controls. }\end{array}$ & {$[40]$} \\
\hline $\begin{array}{l}\text { Products of intestinal microbiota and autoimmune T-cells in } \\
\text { type I diabetes }\end{array}$ & $\begin{array}{l}\text { Acetate significantly reduced the frequency of auto-reactive T-cells in lymphoid } \\
\text { tissues via an effect on } \beta \text {-cells and the ability to expand of auto-reactive T-cells. Diets } \\
\text { with butyrate increased the amount and function of regulatory T-cells, while diets } \\
\text { producing acetate and butyrate protect the gut integrity and reduce the serum level } \\
\text { of diabetogenic cytokines like IL-2I. }\end{array}$ & {$[4 I]$} \\
\hline
\end{tabular}

that protective potentials of SCFAs on $\beta$-cells and endogenous FFA2 expression probably accounted for this effect. Based on prior reports, it was concluded that sodium acetate and propionate reduced islet cell death elicited by cytokine or palmitate; FFA2 deficiency induced $\beta$-cell death and decreased $\beta$-cell mass, whereas SCFAs protected islet $\beta$-cells. ${ }^{17}$

Low grade inflammation and high level of cytokines like IL-6, IL-1, or TNF- $\alpha$ are characteristic features of Type 2 diabetes. These inflammatory markers are expressed in insulin target tissues, such as liver, adipose tissue, and muscles, hence leading to insulin insensitivity. It was investigated that changes in the gut microbial ecosystem provokes a pro-inflammatory condition in the adipose tissue that is related to obesity and resultant insulin resistance. The diversity of the gut microbiota, and its subsequent metabolic products is highly modified by diet changes; proper use of dietary fibers is usually correlated with a level of SCFA that could promote an anti-inflammatory effect, while a higher fat consumption was linked to reduced profile of SCFAs and raised LPS, implying aggregation of $\mathrm{G}^{-\mathrm{ve}}$ bacteria. LPS was found to elicit the generation of pro-inflammatory molecules that are taking part in enhancing permeability and inflammation in the gut epithelium, the so-called "metabolic endotoxemia". ${ }^{16}$

Regulation of BGLs, insulin insensitivity, and GLP-1 release in improving metabolic function is as a result of expressed SCFA receptors in various tissues, hence are able to induce a protective effect provoked by them. The blood glucose lowering potential of SCFAs might be because of their beneficial effects such as: reduced inflammatory condition, hence decreases insulin insensitivity enhance decreased inflammatory state that reduces insulin resistance, simultaneously enhances the release of GLP-1 that promotes insulin release, and ameliorate $\beta$-cell function, thereby helping to maintain glucose homeostasis. Different preclinical and clinical trials showed that the acetate has a role in host energy and substrate metabolism through its positive effect on the release of GLP-1 and peptide YY, therefore affecting appetite by reducing lipolysis, pro-inflammatory mediators, and increasing utilization of energy and fat oxidation. ${ }^{16,18}$

\section{Mechanisms Involving Bile Acids}

BAs are metabolites of cholesterol catabolism in the liver and their synthesis accounts for about half of the daily cholesterol output, whereas $40 \%$ of the output is because of biliary secretion, and the remaining $10 \%$ is employed for membrane and steroid hormone synthesis. As a result, BA metabolism has a central role in regulating cholesterol homeostasis. Extensive research regarding BAs has created a ground for viewing them as signaling molecules that activate several nuclear receptors: farnesoid $\mathrm{X}$ receptor (FXR), vitamin D receptor (VDR), pregnane $\mathrm{X}$ receptor (PXR); and the membrane GPCRs: Takeda GPCR 5 (TGR5), sphingosine-1 phosphate receptor 2 (S1PR2), and muscarinic M2 receptor. These BA stimulated receptors have a significant role in liver metabolism, and the roles of FXR and TGR5 in regulating metabolism and pathophysiology of liver based metabolic diseases has been investigated. ${ }^{19,20}$ The human BA pool is determined by the enterohepatic cycle and microbial metabolism in the 
Table 2 Evidences from Animal and Human Studies Revealing the Causal Relation between Gut Microbiota and Type 2 Diabetes

\begin{tabular}{|c|c|c|}
\hline Study/Method/Intervention & Outcome & Ref \\
\hline $\begin{array}{l}\text { Characteristics of gut microbiota to Chinese herbal formula elderly with } \\
\text { metabolic syndrome }\end{array}$ & $\begin{array}{l}\text { Treatment with a Chinese herbal preparation (Yangyin Tiluo Decoction } \\
\text { (YTD)) decreased the availability of genus Bacteroidales Incertae Sedis } \\
\text { and species Enterobacteriaceae Incertae Sedis. The amount of plasma } \\
\text { lipoprotein (a) also lowered that was negatively associated with the } \\
\text { availability of Acinetobacter species. The finding illustrated domination of } \\
\text { Firmicutes and Actinobacteria, and pointed out visible microbiota in } \\
\text { elder patients with metabolic syndrome which might contribute to the } \\
\text { pathogenesis. Besides, the advantage of the herbal formulation in } \\
\text { complementing the strategy to manage metabolic syndrome was also } \\
\text { noted. }\end{array}$ & {$[42]$} \\
\hline $\begin{array}{l}\text { Recent advances in gut related pharmacology of metformin in type } 2 \\
\text { diabetic patients }\end{array}$ & $\begin{array}{l}\text { The study showed withdrawal of metformin produces a decrease in the } \\
\text { active and total GLP-I and increment in the level of serum bile acids, } \\
\text { specifically cholic acid and its conjugates. However, these were returned } \\
\text { while metformin was readministered. The changes in effects on } \\
\text { circulating peptide tyrosine-tyrosine (PYY) were remarkable, while } \\
\text { minimal on GIP. } \\
\text { The availability of phylum Firmicutes was positively associated with } \\
\text { alterations in cholic acid and its conjugates, whereas availability of } \\
\text { bacteroidetes had a negative correlation. The study suggested that } \\
\text { metformin has multiplex pharmacologic effects because of gut related } \\
\text { mechanisms that could provide a highlight for future scrutiny into novel } \\
\text { treatment modalities in type } 2 \text { diabetes and related metabolic disorders. }\end{array}$ & {$[43]$} \\
\hline $\begin{array}{l}\text { Characteristics of gut microbiota in adults with type I and type } 2 \\
\text { diabetes considering next-generation sequencing of gene fragment of I6S } \\
\text { rRNA }\end{array}$ & $\begin{array}{l}\text { The investigation revealed a negative association of many genera of } \\
\text { bacteria and the percentage of glycated hemoglobin Alc in the type } 2 \\
\text { diabetic group, but a positive association was seen between the bactria in } \\
\text { genus Bifidobacterium and HDL cholesterol levels in both type I and type } \\
2 \text { diabetic groups. } \\
\text { Findings provided a highlight for future investigation in the area of gut } \\
\text { microbiota to bring individualized therapy into the clinical scenario for } \\
\text { patients with diabetes considering the composition of the gut as a novel } \\
\text { approach for managing glycemia. Next-generation sequencing provides a } \\
\text { better identification of DNA of all bacteria found in the sample and their } \\
\text { taxonomic placement. }\end{array}$ & [44] \\
\hline $\begin{array}{l}\text { Gut microbiota markers in obese adolescent and adult patients: Age- } \\
\text { dependent differential patterns }\end{array}$ & $\begin{array}{l}\text { The result showed a characterstic feature of gut microbiota in relation to } \\
\text { ecological feature, microbial make-up, and metabolism in obese patients. } \\
\text { Identifying novel obesity bacterial markers may pave the way for } \\
\text { developing patient-customized treatments in consideration of age-related } \\
\text { microbiota profile. }\end{array}$ & {$[45]$} \\
\hline Gut microbiota in aAdults with type 2 diabetes and those without & $\begin{array}{l}\text { The proportion of phylum Firmicutes and class Clostridia were markedly } \\
\text { lowered in the diabetic group as compared to the control. Moreover, the } \\
\text { ratio of Bacteroidetes to Firmicutes and Bacteroides to Prevotella to C. } \\
\text { coccoides-E. rectale group showed a positive association with plasma } \\
\text { glucose level but not with BMls. } \\
\text { Likewise, class Betaproteobacteria were abundant in diabetic adults as } \\
\text { compared to persons without and a positive association was recorded } \\
\text { with plasma glucose. The study pointed out that type } 2 \text { diabetes is } \\
\text { related to compositional changes of gut microbiota. In addition, to } \\
\text { develope modalities to manage metabolic disorders via modification of } \\
\text { gut microbiota, the emergence of glucose tolerance should be } \\
\text { considered. }\end{array}$ & {$[46]$} \\
\hline
\end{tabular}


Table 2 (Continued).

\begin{tabular}{|c|c|c|}
\hline Study/Method/Intervention & Outcome & Ref \\
\hline $\begin{array}{l}\text { Alterations in human gut microbiota and its effects on glucose } \\
\text { intolerance }\end{array}$ & $\begin{array}{l}\text { Characterizing gut microbiota was performed using } 16 \mathrm{~S} \text { rDNA-based } \\
\text { high-throughput sequencing. Dysbiosis due to type } 2 \text { diabetes, } \\
\text { separation of microbial communities and alteration of alpha diversity } \\
\text { between the different glucose intolerance statuses were reported. } \\
\text { At genus level, availability of Bacteroides in type } 2 \text { diabetic group was } \\
\text { half of the normal glucose tolerance and pe-diabetic group. Prior } \\
\text { report indicated that type } 2 \text { diabetes-related markers were also } \\
\text { compared with findings in this study, and some inconsistencies were } \\
\text { observed. It was identified that Verrucomicrobiae could be one } \\
\text { promising marker of type } 2 \text { diabetes as its abundance was } \\
\text { markedly reduced in both the pre-diabetic and type } 2 \text { diabetic } \\
\text { groups. }\end{array}$ & [47] \\
\hline $\begin{array}{l}\text { Structural modifications of gut macrobiota in type } 2 \text { diabetic and } \\
\text { hyperlipidemia patients treated by metformin and Chinese herbal } \\
\text { preparation: a multicenter, randomized, open label cinical trial }\end{array}$ & $\begin{array}{l}\text { Both metformin and the herbal formula substantially reduced } \\
\text { hyperglycemia and hyperlipidemia and produced structural } \\
\text { alterations in diabetic patients. There was a marked increase in a co- } \\
\text { abundant group called Blautia spp., which was highly related with } \\
\text { positive regulation of glucose and lipid homeostasis. The designed } \\
\text { herbal preparation, however, showed enhanced efficacies in } \\
\text { improving a homeostasis model assessment of insulin resistance and } \\
\text { plasma triglyceride and also exhibits a pronounced effect in gut } \\
\text { microbiota. } \\
\text { Moreover, the herbal preparation raised the co-abundant group, ie, } \\
\text { Faecalibacterium spp. that was investigated before with another study } \\
\text { to be correlated with amelioration of T2DM in a randomised clinical } \\
\text { trial. In conclusion, Metformin and the Chinese herbal formula } \\
\text { probably improve type } 2 \text { diabetes with hyperlipidemia by increasing } \\
\text { the abundance of via bacteria, such as Blautia and Faecalibacterium } \\
\text { spp. }\end{array}$ & [48] \\
\hline The status of gut microbiome in pre-diabetes and type 2 diabetes & $\begin{array}{l}\text { Those phyla with higher availability were: Bacteroidetes, Firmicutes, } \\
\text { Proteobacteria, Verrucomicrobia, and Actinobacteria. The Class Chloracido } \\
\text { bacteria were raised in prediabetes in comparison to type } 2 \text { diabetes. } \\
\text { Unidentified genus from Pseudonocardiaceae was substantially found in } \\
\text { the prediabetic group as compared to others. Genus Collinsella, and an } \\
\text { unknown genus from Enterobacteriaceae were both found to be } \\
\text { significantly increased in type } 2 \text { diabetes compared to the other } \\
\text { groups. } \\
\text { The finding indicated that dysbiosis was correlated with both } \\
\text { prediabetes and type } 2 \text { diabetes, particularly at level of class and genus } \\
\text { implying that prior treatment in prediabetes might provoke transition } \\
\text { of consequences of gut microbiome to type } 2 \text { diabetes. }\end{array}$ & [49] \\
\hline $\begin{array}{l}\text { The effect of metformin on gut microbiome of new case of type } 2 \\
\text { patients }\end{array}$ & $\begin{array}{l}\text { Using a model illustrating metformin- microbiota relationship, it was } \\
\text { revealed that metformin was shown to affect pathways sharing similar } \\
\text { biological roles in species from two distinict phyla, and the majority of } \\
\text { genes regulated by metformin in these species encoded metalloproteins. } \\
\text { The study, therefore, provided ground to strengthen the idea that } \\
\text { alterations in gut microbiota are mediated by some anti-diabetic effects } \\
\text { of metformin. }\end{array}$ & [50] \\
\hline
\end{tabular}

(Continued) 
Table 2 (Continued).

\begin{tabular}{|c|c|c|}
\hline Study/Method/Intervention & Outcome & Ref \\
\hline $\begin{array}{l}\text { Dysbiosis signatures of gut microbiome in the sequence from healthy, } \\
\text { young patients to those with overweight and obesity }\end{array}$ & $\begin{array}{l}\text { Groups with overweight and obesity showed a higher disruption in glycemic } \\
\text { control, lipid profile, and inflammatory markers; patients with acanthosis } \\
\text { nigricans were found in worse metabolic condition with lowered microbiota } \\
\text { diversity. However, quite different microbiota compositions were observed } \\
\text { in those with obesity and healthy volunteers. } \\
\text { Functional analysis indicated a remarkable rise in LPS biosynthetic proteins } \\
\text { and bacterial invasion of epithelial cells-related genes while a remarkable } \\
\text { reduction in glucose and essential amino acid associated genes. Gut } \\
\text { microbiotas and their functions were significantly altered in obesity. Future } \\
\text { investigations emphasizing the association and causality of microbiota and } \\
\text { obesity are crucial and could take part towards the prevention, diagnosis, } \\
\text { and treatment of obesity. }\end{array}$ & [5। $]$ \\
\hline $\begin{array}{l}\text { Alterations in fecal bacterial ecosystem and fermentation products in } \\
\text { obese patients undergoing bilio-intestinal bypass surgery }\end{array}$ & $\begin{array}{l}\text { About half a year post-surgery, metabolic markers like body weight, } \\
\text { glucose, and lipid metabolism were well improved in comparsion to the } \\
\text { standard. Generally, composition of fecal micobiata after surgery was } \\
\text { distinguished with a reduction in bacterial diversity of Lachnospiraceae, } \\
\text { Clostridiaceae, Ruminococcaceae, Eubacteriaceae, and } \\
\text { Coriobacteriaceae. However, a marked rise in genera Lactobacillus, } \\
\text { Megasphaera, and Acidaminococcus and family Enterobacteriaceae was } \\
\text { shown. } \\
\text { The level of SCFA was changed with a minimum abundance of acetate } \\
\text { and propionate and greater amount of valerate and hexanoate. Partly } \\
\text { altrations in bacterial ecosystem is correlated with changes in metabolic } \\
\text { parameters, such as Gemmiger and glucose, Lactobacillus and glucose, and } \\
\text { Faecalibacterium and triglycerides. }\end{array}$ & [52] \\
\hline Circulating succinate I human obesity and its impact on gut microbiota & $\begin{array}{l}\text { Metabolic products of gut microbiota are becoming promising } \\
\text { biomarkers for cardiovascular disease. The level of circulating succinate } \\
\text { which is a metabolic product of both microbiota and the host is found to } \\
\text { rise in cases of hypertension, IHD, and type } 2 \text { diabetes. } \\
\text { Studies revealed the correlation of circulating succinate with specific } \\
\text { metagenomic signatures in cross-sectional and prospective cohorts of } \\
\text { Caucasian Spanish subjects. Obesity was related to increased level of } \\
\text { circulating succinate in line with weakened glucose metabolism which } \\
\text { was rationalized as a result of alterations in succinate metabolism linked } \\
\text { to gut microbiota or a relatively high amount of succinate-producing } \\
\text { Prevotellaceae and Veillonellaceae, and a reduced level of succinate- } \\
\text { consuming Odoribacteraceae and Clostridaceae in those with obesity. }\end{array}$ & [53] \\
\hline $\begin{array}{l}\text { Modulating gut microbiota dysbiosis using macrobiotic Ma-Pi } 2 \text { diet in } \\
\text { type } 2 \text { diabetic individuals }\end{array}$ & $\begin{array}{l}\text { The effect of diet enriched with fibre (macrobiotic Ma-Pi } 2 \text { diet) or a } \\
\text { control diet for type } 2 \text { diabetes treatment was explored. According to } \\
\text { the findings, groups placed on both diet showed better modulation } \\
\text { dysbiosis in type } 2 \text { diabetes, which therefore improves the diversity of } \\
\text { the gut ecosystem and helps SCFA to recover those participated to } \\
\text { produce SCFA such as Faecalibacterium, Roseburia, Lachnospira, } \\
\text { Bacteroides, and Akkermansia. } \\
\text { Pro-inflammatory ones like Collinsella and Streptococcus were reduced } \\
\text { in the gut in groups taking Ma-Pi } 2 \text { diet, but not the case in the controls, } \\
\text { which might be due to its capacity to counteract pro-inflammatory } \\
\text { dysbioses in type } 2 \text { diabetes, and probably better response for the } \\
\text { metabolic control. }\end{array}$ & [54] \\
\hline
\end{tabular}


Table 2 (Continued).

\begin{tabular}{|c|c|c|}
\hline Study/Method/Intervention & Outcome & Ref \\
\hline $\begin{array}{l}\text { Metagenomic sequencing of the gut microbiome pre- and post-bariatric } \\
\text { surgery in obese type } 2 \text { diabetic patients: association with inflammatory } \\
\text { and metabolic parameters }\end{array}$ & $\begin{array}{l}\text { The overall metagenomic Roux-en-Y gastric bypass (RYGB)- elicited shift } \\
\text { was distinguished with decreased Firmicutes and Bacteroidetes and } \\
\text { raised Proteobacteria. Twenty-two microbial communities and II genera } \\
\text { were substantially modulated by RYGB. Functional analysis of } \\
\text { carbohydrate metabolism by KEGG Orthology (KO) illustrated } \\
\text { remarkable results in I3 KOs using phosphortransferase systems. } \\
\text { Spearmen's Rank correlation showed the association of } 10 \text { species with } \\
\text { plasma total or LDL, and five species with TGs, whereas F. prausnitzii had } \\
\text { a direct correlation with FBG. A distinct association was found to exist } \\
\text { between microbiome constitution and gene function with improving } \\
\text { potential in metabolic and inflammatory parameters, and it provides } \\
\text { evidence to bring novel diagnostic and therapeutic approaches based on } \\
\text { metagenomic sequencing of human gut microbiome. }\end{array}$ & [55] \\
\hline Status of insulin sensitivity after lean donor feces in metabolic syndrome & $\begin{array}{l}\text { Post-allogeneic FMT at } 6 \text { weeks, showed improvement in insulin } \\
\text { sensitivity along with alteration in microbiota composition. The } \\
\text { protective role of lean donor FMT on glucose metabolism is linked with } \\
\text { the change in gut microbiota and plasma metabolites and is estimated } \\
\text { from the baseline fecal microbiota composition. }\end{array}$ & [56] \\
\hline Role of butyrate in insulin sensitivity and energy expenditure in mice & $\begin{array}{l}\text { On HFD, feeding with butyrate reduced the occurrence of insulin } \\
\text { insensitivity and obesity in C57BL/6 mice. FBG, fasting insulin, and insulin } \\
\text { tolerance were all maintained in treated mice. Enhancement of adaptive } \\
\text { thermogenesis and FA oxidation were noted. Enhanced function of } \\
\text { mitochondrian and biogenesis was skeletal muscle and brown fat. }\end{array}$ & [57] \\
\hline $\begin{array}{l}\text { Cultured gut microbiota from twins discordant for obesity and its impact } \\
\text { on and metabolic phenotypes in mice }\end{array}$ & $\begin{array}{l}\text { Group homed mice nurturing in obese twin's micr biota with mice } \\
\text { containing the lean co-twin's microbiota averted the increment in body } \\
\text { mass and obesity-correlated metabolic phenotypes in obese cagemates. } \\
\text { Rescue linked with overwhelming of certain members of Bacteroidetes } \\
\text { from the lean microbiota into obese microbiota, and was diet-dependent. }\end{array}$ & [58] \\
\hline $\begin{array}{l}\text { The effect } f \text { nuclear receptor FXR in GLP-I secretion for microbiota- } \\
\text { derived SCFAs }\end{array}$ & $\begin{array}{l}\text { The finding illustrated that FXR stimulation reduces L-cell GLP-I release } \\
\text { in response to inulin-derived SCFA by decreasing FFAR2 expression and } \\
\text { signalling. Inactivation of gut FXR with BA binding agens or synthetic } \\
\text { ntagonistsin adjuvant with prebiotic supplementation could be a } \\
\text { promising treatment strategy to augment incretin axis in type } 2 \text { DM. }\end{array}$ & [59] \\
\hline $\begin{array}{l}\text { Gut microbiota from twins discordant for obesity and role in metabolism } \\
\text { in mice }\end{array}$ & $\begin{array}{l}\text { The intact and cultured bacterial component of obese co twin's faecal } \\
\text { micro biota brought a more marked rise in body mass and adiposity than } \\
\text { the leans. } \\
\text { The variation in body mass was associated with changes in fermentation } \\
\text { of SCFAs (raised in the leans), and metabolism of branched-chain amino } \\
\text { acids (increased in obese), and microbial transformation of BA (increased } \\
\text { in lean and linked with down-regulation of host FXR signaling). }\end{array}$ & [58] \\
\hline
\end{tabular}

gut (Figure 2). BAs can undergo decongugations induced by a broad spectrum of gut bacteria. Therefore, regarding the level of BAs excreted in feces, the majority contain secondary BAs, and highly rely on gut microbiota metabolism. $^{21}$

Recent data suggests that dysregulation in luminal enteral communication because of BA sequestrants could reveal the attractive effects of these drugs. Various gastrointestinal cells and hormones work together to contribute in neuroendocrine regulation of digestion and metabolic function. Detecting a way to augment endogenous GLP1 secretion, without increasing overall energy intake and deposition, is an attractive concept in the future treatment of type 2 diabetes - simultaneously improving our 


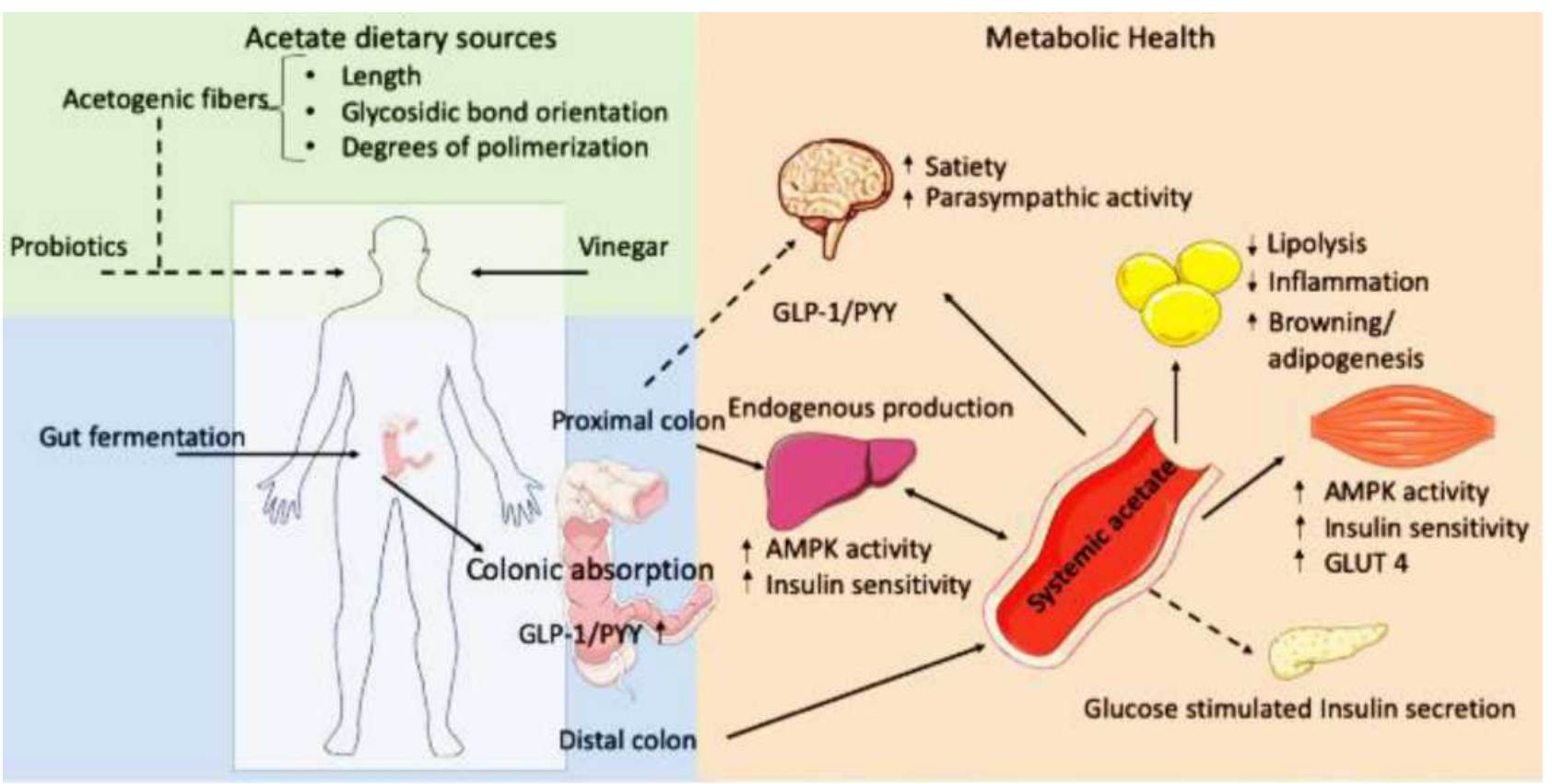

Figure I Acetate and effects in metabolic health. The solid lines show well studied effects of acetate, while broken lines imply more inconsistent findings. Reproduced from Hernández MAG, Canfora EE, Jocken JWE, Blaak EE. The Short Chain Fatty Acid Acetate in Body Weight Control and Insulin Sensitivity. Nutrients. 2019;1।(1943). ${ }^{18}$ Copyright () 2019 by the authors. Licensee MDPI, Basel, Switzerland. Creative Commons Attribution (CC BY) license (http://creativecommons.org/licenses/by/4.0/).

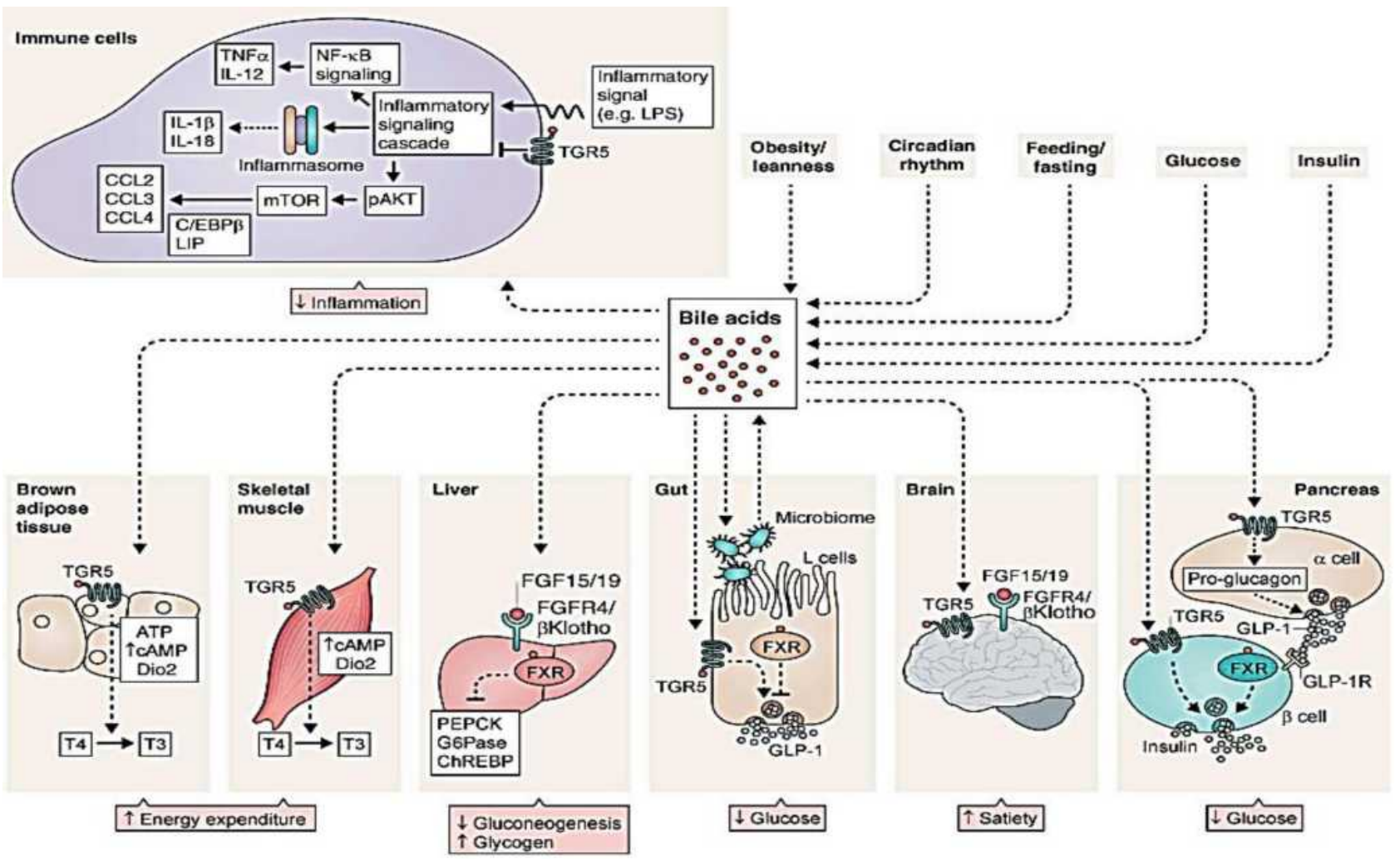

Figure 2 BA signaling controls the systemic glycemic response. Reproduced from Shapiro H, Kolodziejczyk AA, Halstuch D, Elinav E. Bile acids in glucose metabolism in health and disease. J ExpMed. 2018;215(2):383-396. ${ }^{20}$ Copyright (C) 2018 Shapiro et al. Creative Commons License (Attribution-Noncommercial-Share Alike 4.0 International license, as described athttps://creativecommons.org/licenses/by-nc-sa/4.0/). 
understanding of endocrine gut physiology. ${ }^{22}$ To date, the use of BA chelates are the only treatment modalities for diabetes involving BA, however, it was revealed that part of the advantages of bariatric surgery on controlling glucose level in diabetic patients is something associated with BA metabolism. ${ }^{23}$

In the brain, BA-TGR5 cascading regulates satiety. In skeletal muscles and brown adipose tissue, BA-TGR5 sensing enhances the conversion of $\mathrm{T} 4$ to $\mathrm{T} 3$, provoking a rise in energy expenditure. In the pancreas, both BATGR5 and BA-FXR signaling in $\beta$-cells stimulates insulin production. Glucose-induced insulin release is also enhanced by BA-TGR5 signaling in $\alpha$-cells, that promotes proglucagon to be changed to GLP-1 and GLP-1 release. TGR5-BA in immune cells inhibits NLRP3-inflammasome and reduced inflammation.

\section{Conclusion}

The current review of aggregate evidence from animal and human investigations has shown that dysbiosis in gut microbial ecosystem and reduction of their diversity was associated with the onset and progression of both types of diabetes. The possible mechanisms include the generation of SCFAs in distal gut is via bacterial fermentation of macrofibrous material that might get out of digestion by upper gastrointestinal tract participates in modulating CNS, gut barrier axis, and immune system which are assumed to be promising mechanisms for the observed protective effects of SCFAs on diabetes pathogenesis. Furthermore, extensive research regarding BAs has created a ground for viewing them as signaling molecules that activate several nuclear receptors in regulating metabolism and pathophysiology of liver based metabolic diseases. Considering these findings, the research community should give emphasis on studies illustrating the significance of maintaining healthy microbial composition because related findings could be useful for developing strategies to control diabetes by modifying the gut microbiota. In fact, bringing these understandings into reasonable therapeutic measures is challenging. Therefore, in the future, ongoing randomized controlled trials in huge human cohorts are needed to uncover unresolved questions and prove the efficacy of microbiota-based therapeutic approaches.

\section{Author Contributions}

Both authors made a significant contribution to the work reported, whether that is in the conception, study design, execution, acquisition of data, analysis and interpretation, or in all these areas; took part in drafting, revising, or critically reviewing the article; gave final approval of the version to be published; have agreed on the journal to which the article has been submitted; and agree to be accountable for all aspects of the work.

\section{Disclosure}

The authors report no conflicts of interest for this work.

\section{References}

1. Punthakee Z, Goldenberg R, Katz P, et al. Definition, classification and diagnosis of diabetes, prediabetes and metabolic syndrome. Can J Diabetes. 2018;42:S10-S15. doi:10.1016/j.jcjd.2017.10.003

2. Ubaid M, Arif M, Usmani A, Anayatullah KN, Dash PP, Mishra A. Advances in clinical endocrinology and metabolism: an insight to diabetes mellitus and its complications. Adv Clin Endo Met. 2019;2 (1):37-46.

3. Olokobam AB, Obateru OA, Olokoba LB. Type 2 diabetes mellitus: a review of current trends. Oman Med J. 2012;27(4):269-273. doi:10.5001/omj.2012.68

4. Baynes HW. Classification, pathophysiology, diagnosis and management of diabetes mellitus. J Diabetes Metab. 2015;6:541. doi:10.4172/2155-6156.1000541

5. Ma Q, Li Y, Li P, et al. Research progress in the relationship between type 2 diabetes mellitus and intestinal flora. Biomed Pharmacother. 2019;117:109138.

6. Xu H, Liu M, Cao J, et al. The dynamic interplay between the gut microbiota and autoimmune diseases. J Immunol Res. 2019.

7. Durazzo M, Ferro A, Gruden G. Gastrointestinal microbiota and type 1 diabetes mellitus: the state of art. J Clin Med. 2019;8:1843. doi: $10.3390 / \mathrm{jcm} 8111843$

8. Wang H, Wei CX, Min L, Zhu LY. Good or bad: gut bacteria in human health and diseases. Biotechnol Biotechnol Equip. 2018;32 (5):1075-1080. doi:10.1080/13102818.2018.1481350

9. Zhou H, Sun L, Zhang S, Zhao X, Gang X, Wang G. Evaluating the causal role of gut microbiota in type 1 diabetes and its possible pathogenic mechanisms. Front Endocrinol (Lausanne). 2020;11:125. doi:10.3389/fendo.2020.00125

10. Hsiao WW, Metz C, Singh DP, Roth J. The microbes of the intestine: an introduction to their metabolic and signalling capabilities. Endocrinol Metab Clin North Am. 2008;37(4):857-871. doi:10.1016/j.ecl.2008.08.006

11. Wen L, Duffy A. Factors Influencing the gut microbiota, inflammation, and type 2 diabetes. $J$ Nutr. 2017;147:1468S-1475S. doi:10.3945/jn.116.240754

12. Lazar V, Ditu L-M, Pircalabioru GG, et al. Gut microbiota, host organism, and diet trialogue in diabetes and obesity. Front Nutr. 2019;6:21. doi:10.3389/fnut.2019.00021

13. Aw W, Shinji Fukuda S. Understanding the role of the gut ecosystem in diabetes mellitus. J Diabetes Investig. 2018;9:5-12. doi:10.1111/ jdi. 12673

14. Olden CV, Groen AK, Nieuwdorp M. Role of intestinal microbiome in lipid and glucose metabolism in diabetes mellitus. Clin Ther. 2015;37(6).

15. Kim $\mathrm{CH}$. Microbiota or short-chain fatty acids: which regulates diabetes? Cell Mol Immunol. 2018;15:88-91. doi:10.1038/cmi.2017.57

16. Puddu A, Sanguineti R, Montecucco F, Viviani GL. Evidence for the gut microbiota short-chain fatty acids as key pathophysiological molecules improving diabetes. Mediators Inflamm. 2014;1-9. doi:10.1155/2014/162021 
17. Liu JL, Segovia I, Yuan XL, Gao ZH. Controversial roles of gut microbiota-derived short-chain fatty acids (SCFAs) on pancreatic $\beta$ cell growth and insulin secretion. Int J Mol Sci. 2020;21:910. doi:10.3390/ijms 21030910

18. Hernández MAG, Canfora EE, Jocken JWE, Blaak EE. The short chain fatty acid acetate in body weight control and insulin sensitivity. Nutrients. 2019;11:1943. doi:10.3390/nu11081943

19. Ferrell JM, Chiang JYL. Understanding Bile Acid Signaling in Diabetes: from Pathophysiology to Therapeutic Targets. Diabetes Metab J. 2019;43:257-272. doi:10.4093/dmj.2019.0043

20. Shapiro H, Kolodziejczyk AA, Halstuch D, Elinav E. Bile acids in glucose metabolism in health and disease. $J$ Exp Med. 2018;215 (2):383-396. doi:10.1084/jem.20171965

21. Molinero N, Ruiz L, Sánchez B, et al. Intestinal bacteria interplay with bile and cholesterol metabolism: implications on host physiology. Front Physiol. 2019;10:185. doi:10.3389/fphys.2019.00185

22. Sonne DP, Hansen M, Knop FK. Bile acid sequestrants in type 2 diabetes: potentialeffects on GLP1 secretion. European Journal of Endocrinology. 2014;171(2):R47-R65. doi:10.1530/EJE-14-0154

23. González-Regueiro JA, Moreno-Castañeda L, Uribe M, et al. The role of bile acids in glucose metabolism and their relation with diabetes. Ann Hematol. 2018;16(1):s15-s20. doi:10.5604/01.3001. 0010.5672

24. Huang Y, Li S-C, Hu J, et al. Gut microbiota profiling in Han Chinese with type 1 diabetes. Diabetes Res Clin Pract. 2018;141:256-263. doi:10.1016/j.diabres.2018.04.032

25. Cinek O, Kramna L, Mazankova K, et al. The bacteriome at the onset of type 1 diabetes: a study from four geographically distant African and Asian countries. Diabetes Res Clin Pract. 2018;144:51-62. doi:10.1016/j.diabres.2018.08.010

26. De Goffau MC, Luopajarvi K, Knip M, et al. Fecal microbiota composition differs between children with b-cell autoimmunity and those without. Diabetes. 2013;62:1238-1244. doi:10.2337/db12-0526

27. Murri M, Leiva I, Gomez-Zumaquero JM, et al. Gut microbiota in children with type 1 diabetes differs from that in healthy children: a case-control study. $+n$. 2013;11:46.

28. Leiva-Gea I, Sánchez-Alcoholado L, Martín-Tejedor B, et al. Gut microbiota differs in composition and functionality between children with type 1 diabetes and MODY2 and healthy control subjects: a case-control study. Diabetes Care. 2018;41:2385-2395. doi:10.2337/ dc18-0253

29. Higuchi BS, Rodrigues N, Gonzaga MI, et al. Intestinal dysbiosis in autoimmune diabetes is correlated with poor glycemic control and increased interleukin-6: a pilot study. Front Immunol. 2018;9:1689. doi:10.3389/fimmu.2018.01689

30. Pinto E, Anselmo M, Calha M, et al. The intestinal proteome of diabetic and control children is enriched with different microbial and host proteins. Microbiology. 2017;163:161-174. doi:10.1099/ mic. 0.000412

31. Brown CT, Davis-Richardson AG, Giongo A, et al. Gut microbiome metagenomics analysis suggests a functional model for the development of autoimmunity for type 1 diabetes. PLoS One. 2011;6(10): e25792. doi:10.1371/journal.pone.0025792

32. De Groot PF, Belzer C, Aydin Ö, et al. Distinct fecal and oral microbiota composition in human type 1 diabetes, an observational study. PLoS One. 2017;12(12):e0188475. doi:10.1371/journal.pone. 0188475

33. Gürsoy S, Koçkar T, Atik SU, et al. Autoimmunity and intestinal colonization by Candida albicans in patients with type 1 diabetes at the time of the diagnosis. Korean J Pediatr. 2018;61(7):217-220. doi:10.3345/kjp.2018.61.7.217

34. Kostic AD, Gevers D, Siljander H, et al. The dynamics of the human infant gut microbiome in development and in progression towards type 1 diabetes. Cell Host Microbe. 2015;17(2):260-273. doi:10.1016/j.chom.2015.01.001
35. Soyucen E, Gulcan A, Aktuglu-Zeybek AC, et al. Differences in the gut microbiota of healthy children and those with type 1 diabetes. Pediatr Int. 2014;56:336-343. doi:10.1111/ped.12243

36. De Goffau MC, Fuentes S, van den Bogert B, et al. Aberrant gut microbiota composition at the onset of type 1 diabetes in young children. Diabetologia. 2014;57(8):1569-1577. doi:10.1007/s00125014-3274-0

37. Giongo A, Gano KA, Crabb DB, et al. Toward defining the autoimmune microbiome for type 1 diabetes. Int Soc Microb Ecol. 2011;5:82-91.

38. de Groot P, Nikolic T, Pellegrini S, et al. Faecal microbiota transplantation halts progression of human new-onset type 1 diabetes in a randomized controlled trial. Gut. 2021;70:92-105. doi:10.1136/ gutjnl-2020-322630

39. de Groot P, Nikolic T, Imangaliyev S, et al. Oral butyrate does not affect innate immunity and islet autoimmunity in individuals with longstanding type 1 diabetes: a randomised controlled trial. Diabetologia. 2020;63(3):597-610. doi:10.1007/s00125-019-05073-8

40. Vatanen T, Franzosa EA, Schwager R, et al. The human gut microbiome in early-onset type 1 diabetes from the TEDDY study. Nature. 2018;562:589-594. doi:10.1038/s41586-018-0620-2

41. Mariño E, Richards JL, McLeod KH, et al. Gut microbial metabolites limit the frequency of autoimmune $\mathrm{T}$ cells and protect against type 1 diabetes. Nat Immunol. 2017;18(5):552-562. doi:10.1038/ni.3713

42. Ni Y, Mu C, He X, et al. Characteristics of gut microbiota and its response to a Chinese Herbal Formula in elder patients with metabolic syndrome. Drug Discov Ther. 2018;12(3):161-169. doi:10.5582/ddt.2018.01036

43. Napolitano A, Miller S, Nicholls AW, et al. Novel gut-based pharmacology of metformin in patients with type 2 diabetes mellitus. PLoS One. 2014;9(7):e100778. doi:10.1371/journal.pone.0100778

44. Salamon D, Sroka-Oleksiak A, Kapusta P, et al. Characteristics of gut microbiota in adult patients with type 1 and type 2 diabetes based on next-generation sequencing of the 16S rRNA gene fragment. Pol Arch Intern Med. 2018;128(6):336343. doi:10.20452/pamw.4246

45. Del Chierico F, Abbatini F, Russo A, et al. Gut microbiota markers in obese adolescent and adult patients: age-dependent differential patterns. Front Microbiol. 2018;9:1210. doi:10.3389/ fmicb. 2018.01210

46. Larsen N, Vogensen FK, van den Berg FWJ, et al. Gut microbiota in human adults with type 2 diabetes differs from non-diabetic adults. PLoS One. 2010;5(2):e9085. doi:10.1371/journal.pone.0009085

47. Zhang X, Shen D, Fang Z, et al. Human gut microbiota changes reveal the progression of glucose intolerance. PLoS One. 2013;8(8): e71108. doi:10.1371/journal.pone. 0071108

48. Tong X, Xu J, Lian F, et al. Structural alteration of gut microbiota during the amelioration of human type 2 diabetes with hyperlipidemia by metformin and a traditional Chinese herbal formula: a multicenter, randomized, open label clinical trial. mBio. 2018;9(3): e02392-17. doi:10.1128/mBio.02392-17

49. Lambeth SM, Carson T, Lowe J, et al. Composition, diversity and abundance of gut microbiome in prediabetes and type 2 diabetes. $J$ Diabetes Obes. 2015;2(3):1-7. doi:10.15436/2376-0949.15.031

50. Wu H, Esteve E, Tremaroli V, et al. Metformin alters the gut microbiome of individuals with treatment-naive type 2 diabetes, contributing to the therapeutic effects of the drug. Nat Med. 2017;23(7):850858. doi:10.1038/nm.4345

51. Renyuan Gao R, Zhu C, Li H, et al. Dysbiosis signatures of gut microbiota along the sequence from healthy, young patients to those with overweight and obesity. Obesity. 2018;26(2):351-361. doi:10.1002/oby.22088

52. Patrone V, Vajana E, Minuti A, et al. Postoperative changes in fecal bacterial communities and fermentation products in obese patients undergoing bilio-intestinal bypass. Front Microbiol. 2016;7:200. doi:10.3389/fmicb.2016.00200 
53. Serena C, Ceperuelo-Mallafré V, Keiran N, et al. Elevated circulating levels of succinate in human obesity are linked to specific gut microbiota. ISME J. 2018;12:1642-1657. doi:10.1038/s41396-018-0068-2

54. Candela M, Biagi E, Soverini M, et al. Modulation of gut microbiota dysbioses in type 2 diabetic patients by macrobiotic Ma-Pi 2 diet. $\mathrm{Br}$ J Nutr. 2016;116:80-93. doi:10.1017/S0007114516001045

55. Graessler J, Qin Y, Zhong H, et al. Metagenomic sequencing of the human gut microbiome before and after bariatric surgery in obese patients with type 2 diabetes: correlation with inflammatory and metabolic parameters. Pharmacogenomics J. 2013;13(6):514-522. doi:10.1038/tpj.2012.43

56. Kootte RS, Levin E, Salojärvi J, et al. Improvement of insulin sensitivity after lean donor feces in metabolic syndrome is driven by baseline intestinal microbiota composition. Cell Metab. 2017;26:611-619. doi:10.1016/j.cmet.2017.09.008
57. Gao Z, Yin J, Zhang J, et al. Butyrate improves insulin sensitivity and increases energy expenditure in mice. Diabetes. 2009;58:1509. doi: $10.2337 / \mathrm{db} 08-1637$

58. Ridaura VK, Faith JJ, Rey FE, et al. Gut microbiota from twins discordant for obesity modulate metabolism in mice. Science. 2013;341(6150). doi:10.1126/science. 1241214

59. Ducaste S, Touche V, Trabelsi M-S, et al. The nuclear receptor fXR inhibits glucagon-like peptide-1 secretion in response to microbiotaderived short-chain fatty acids. Sci Rep. 2020;10(1):174. doi:10.1038/ s41598-019-56743-x

\section{Publish your work in this journal}

Diabetes, Metabolic Syndrome and Obesity: Targets and Therapy is an international, peer-reviewed open-access journal committed to the rapid publication of the latest laboratory and clinical findings in the fields of diabetes, metabolic syndrome and obesity research. Original research, review, case reports, hypothesis formation, expert opinion and commentaries are all considered for publication. The manuscript management system is completely online and includes a very quick and fair peer-review system, which is all easy to use. Visit http://www.dovepress.com/testimonials.php to read real quotes from published authors.

Submit your manuscript here: https://www.dovepress.com/diabetes-metabolic-syndrome-and-obesity-targets-and-therapy-journal 